\title{
Inside the Image and the Word: The Re/membering of Indigenous Identities*
}

\author{
Dina Fachin \\ University of California, Davis
}

\section{Introduction}

By appropriating the power of writing of the phonetic Latin alphabet and recent visual technology, new generations of indigenous people from the Americas have been able to articulate and reinforce their own sense of identity from "within" their cultural constructs. In so doing, they have been shaping new narratives of indigenous adaptation and survival based on native ontologies and epistemologies that critically decolonize the homogenizing forces of national and global rhetoric. I argue that the texts under examination put forward ways to conceive and to know individual and communal identity that cannot be understood outside specific, ancient notions of territoriality and re/membering.

In the following essay developed out of an ongoing, larger project on self-representation in indigenous literatures and video making in Mexico, I extend my research to the works of U.S. indigenous writers and scholars such as Laguna Pueblo L. M. Silko and the late Acoma Pueblo Simon Ortiz in order to foster a hemispheric approach to the problematizing of indigeneity. I 
believe that a comparison between the indigenous histories from North and Latin America of the last two decades is imperative to the fostering of intercultural dialogues and to the formulation of research methodologies that respond to the demands and the protocols of the indigenous nations themselves.

In line with most indigenous studies scholars, I claim that self-representation is used by indigenous writers and community videomakers hemispherically as a proposal for social change, as a decolonizing, empowering strategy that unravels the history of colonization. Even though popular culture manifestations ranging from musical bands, fashion, style, and mass media imagery show that younger generations of indigenous men and women in North and Latin America are inclined to assimilate into the mainstream and to leave traditional heritages behind, this essay focuses on alternative responses to the commodization of culture.

My fieldwork in Mexico in 2006 and 2007 as well as some archival research on contemporary indigenous political and cultural grassroot movements led me to the conclusion that several young people are indeed taking a critical look at the homogenizing forces of global and assimilationist policies within their countries. While, for example, some rural communities from the Costa Chica of Oaxaca, Mexico, have materialized these efforts in the realization of community projects for the handmade production of textiles, artifacts and the fostering of self-subsistence economies, the Zapatistas in Chiapas have internationalized their struggles through the consistent and innovative use of communication technologies. By the same token, several indigenous tribes from the U.S. have engaged in language revitalization and educational projects that clearly testify to the need to keep local identities alive and carry on the elders' knowledge and teachings in the native languages. One of the best examples in this direction being the "Harrington Project" coordinated by Prof. Martha Macri at the University of California, Davis and realized with the collaboration of California indigenous tribes. Given these examples and among several significant ones, I believe that a close look at literature and visual production will help us not only understand the potential of images and creative language in fostering cultural awareness, but also the "theoretical" 


\section{Ethnic Studies Review Volume 32.1}

and epistemological foundations of contemporary indigenous activism and grassroots work - both literature and videomaking constituting "organic", intellectual activities within the context of community building.

Over the past twenty years, indigenous and mixed-blood cultural producers have engaged in a conversation with current historical and social changes and made their struggle for survival "visible" by re-mapping key concepts such as ethnic identity, community, autonomy and sovereignty, and territoriality from an emic point of view. In light of this, I will discuss how literature and videomaking offer major contribution to the unmaking of the flat cartography of the conquest and therefore to the restoration of the sacredness and the vitality of the native space to their cosmological order, balance, and multidimensionality. In these textual dynamics, creativity and imagination play the crucial roles of traditional truth seekers and of depositaries of (oral) collective and sacred memories; that is to say, cultural practices related to language and to the visual image recontextualize tradition in a process of innovation and transformation that guarantees its survival, "it is also the case that the "real" tradition is to break with tradition, to desacralize and actualize it." While this approach invites us to acknowledge the epistemic value of the landbase and traditional knowledge as the most important commonalities between indigenous discourses, it also urges us to look at difference as a foundational, decolonizing paradigm that leads to a re-thinking of indigenous identities as specific and distinct from one another. This paper, therefore, is part of a decolonizing project because it ultimately seeks to prove that "self-representation" is a viable tool in the dismantling of hegemonic representational frameworks, and in the assertion and dissemination of local indigenous worldviews.

As we will see in the following pages, indigenous philosophies, pedagogies, spiritual beliefs, political engagement and history are profoundly embedded in languages, storytelling, ritual ceremonies, and in the creative works of most contemporary indigenous cultural producers. By the same token, the works of indigenous studies scholars offer major contribution to "culturally appropriate" theoretical frameworks that question hegemonic canons in the 
investigation and conceptualization of indigenous experiences across the Americas. I argue, therefore, that only by putting in dialogue such different sources will we be able to understand the healing power of both "creative" and academic works, as well as the complementary role that they fulfill in relation to one another.

The first part of this essay, "Understanding through contextualization" looks at the intersections of indigenous cultural production and political activism: I explain that while imperialistic notions of progress and modernization clash with indigenous perspectives, the texts under examination speak to the appropriation and reframing of such notions in more indigenous terms. The following section, "Set in Stone: the language of place writes back to the cartography of the conquest" offers some theoretical reflections by Native American Studies scholars on the epistemological, cosmological and ontological value of the "language of place". The last section, "Choosing the right word: repositioning knowledge, the self, and the community within the cosmos," revolves around the works of some indigenous writers and community videomakers and examines how their narratives contribute to the formulation and enhancement of both individual and collective identity across different, indigenous contexts.

\section{Understanding through contextualization}

Since its very inception, Native American Studies has called for a dialogue across different, academic disciplines and, as most recent scholarship shows, between communities of intellectuals from different ethnic backgrounds, be they native or not. One of the most significant factors in the establishment of Native American Studies as an academic discipline was the indigenous activism of the late 1960s-70s, along with the prolific production of socially committed art and writing. The interdisciplinary, hemispheric nature of this scholarship undermines the social science oriented notion of a specialized knowledge by calling for a holistic approach to Native American experience. This, in fact, is based on an over encompassing knowledge of indigenous political, economic, belief systems, literary works, oral accounts, and traditions.

As ever, the hemispheric framework is now in tune with the 


\section{Ethnic Studies Review Volume 32.1}

expansion, in the international arena, of contemporary activism. Given the problematic relationship between linear notions of progress (promoting modernization, capitalism and globalization) and longstanding principles of sustainability, reciprocity, and moral economy, such an approach helps us understand how Northern and Latin American indigenous people alike have been debating on the "macrohistorical context in which the present world social system developed." Since Columbus' arrival, ideologies of progress and evangelization predicated upon the perception of indigenous territories and natural resources as terra nullius have endorsed imperial designs of expansionism both at the national and international level. Although the modalities of the conquest were different in the two hemispheres, [for the Spaniards] "la conquista no solo significaba la ocupación de territorios sino la conversión de los vencidos. [for the English] la noción de evangelización tuvo un lugar secundario en la expansión colonial inglesa" genocide, diseases, forced assimilation and moral oppression were historical traumas shared by entire populations throughout the continent. Indigenous activism has thus aimed at healing the ruptures of colonialism by recollecting the memory of the earth and of its people, by fostering community cohesion as well as indigenous notions of sharing and reciprocity. These, in fact, should be taken as fundamental, guiding principles in the building of a global world that values ethnic and cultural differences over homogeneity, and that puts the natural environment at the center of international agendas of political and economic development. In the article "Globalization and Traditional Cultures" Shelton Davis couples the role that local communities have in rural (alternative) development with "the recent surge of interest in global environmental issues." However, I argue that political economy and environmentalist approaches are not the only branches of knowledge to which we shall turn to in order to understand the devastating effects of genocide and European invasions on indigenous territories today. Rather, indigenous conceptualizations of the territory, place and the cosmos are deeply rooted in pre-colonial history; these find some of their best expressions in the rich repertoires of traditional storytelling and knowledge that constitute, in their turn, the 
foundations of contemporary indigenous writing and of visual production.

Thanks to translation in literature and to the immediacy of the visual media, indigenous people have furthered the dialogue within - and between - communities across borders. It is the case of Maya-Jakaltec Victor Montejo's translations of Simon Ortiz's work, of Carlos Montemayor's anthological translations of Mexican indigenous poetry, prose and theater, into Spanish (and English) as well as of the recently published anthology of Mexican indigenous poetry Reversible Monuments. By the same token, community videos are being shown not only locally, but also at international festivals: Seeking for Well-Being, for example, was awarded the prize for the Proceso Socio-Organizativo de los Pueblos Indígenas in 1999. With regard to indigenous organizing and political mobilization, these narratives speak to a common, joint effort in the affirmation and preservation of indigenous knowledge in the face of encroaching globalization. Some may also argue that especially the visual image —as in the case of Kayapo videomaking in the Brazilian Amazon - can give way to remarkable examples of "staged" ethnicity. In the "meta-representation" of ritual life, mimesis and replication become contiguous strategies for the construction of social and cultural realities, as well as for the fostering of political engagement,

. . . their supreme dramatic role, their greatest feat of creative mimesis, has undoubtedly been their enactment of themselves in their self-representations to Brazilians and other Westerners, from environmentalists to World Bank executives. These self-representations have played a crucial role in their successful political actions over the past decade. There has been a complex feedback relationship between Kayapo self-dramatization in these political encounters, many of which have taken on an aspect as guerrilla theatre, and the Kayapo use of video media.

On a political level, these narratives unsettle official narratives and bring to the forefront the necessity for "glocal" agendas that legitimize autonomy and self-determination as integral parts of 
national (if not post-national) and international processes: issues of land claiming, environmental policies, and religious rights constitute the core of most video projects both in the Northern and in the Southern hemisphere. Quite illustrative is, in this sense, the Declaration of 2003 World Summit on the information Society that in taking up "the challenge of creating an all-inclusive and equitable information society by bridging the digital divide between developed and developing nations" has come to acknowledge (at least on the paper) indigenous peoples' rights to self-determination in the use of information technology. As Wilmer claims, far from totally rejecting modernization and progress, indigenous people adopt them "in a manner consistent with their own cultural context. They advocate the right to choose the degree and terms of their interaction with other cultures." In so testifying to this negotiation between "colonial and indigenous" understandings of the world, these works stand out as sound examples of cultural resilience and as invaluable tools of inquiry into the complexities of contemporary, indigenous identity.

\section{Set in stone: the language of place writes back to the cartography of the conquest}

In his essay "Una dialéctica negada. Notas sobre la multietnicidad mexicana," Stefano Varese stresses on the role of language in the shaping of distinct, ethnic identities,

El índice sintético de una etnicidad ergo de su cultura es el idioma. Las lealtades del grupo social hacia su universo semántico, la solidaridad individual hacia aquellos que comparten este universo semántico, es la definición operacional con la cual puede manejar un concepto antropológico tan manoseado como el de la cultura.

If, on the one hand, his analysis is undoubtedly appropriate in relation to (indigenous) cultures from Mexico, a country where native languages are still widely spoken, on the other, it leaves room for more reflections on the colonial history of the U.S. That is, how can we apply the linguistic criteria to the definition of a culture/ethnicity in those contexts where the language has been 
completely eradicated or is only now in the process of being revitalized? I suggest considering the term "language" beyond its "verbal" connotation and extending it to the sphere of social practices that weave in the fabric of indigenous "cultural identities." In fact, the long history of indigenous resistance to colonial practices on both hemispheres testifies to the resilience of indigenous ways of signifying the world not only through the use of language but also ceremonies, dances, visual representation, etc.

As recent decolonizing projects ranging from creative, to environmental, educational, political initiatives etc. clearly show, shared histories of genocide, forced assimilation, and social dismemberment have produced discourses of ethnic and cultural identity articulated and rooted in notions of culture that put the land at the center of the individual experience and within the context of original peoples' ethics, ways of knowing, belief-systems and (as noted above) of ancient memory. Consequently, native perceptions of the space and the time we are living in emerge from views of existence that cannot exist outside the grammar of respect and reciprocity between individuals, communities and the land. The earth itself is also the source and nurturer of the language of place whereby native people articulate and renew their own sense of identity and respond to centuries of colonialism and of forced acculturation.

Although this emphasis on the connection between the individual and the place has been dismantled by postmodern theories in orderto justify the formulation of a hybrid, "unrooted" and — I would add — "placeless" identity, I agree with Sandy Grande's observation that, "While American Indian intellectuals also seek to embrace the notion of transcendent subjectivities, they seek a notion of transcendence that remains rooted in historical place and the sacred connection to land." This, however, is not to say that identity is static and predetermined - and even less so, is this the case for place and time; indeed, it is mostly positional, strategic, and largely (but not exclusively) a function of remembering, ". . . our individuality is not produced in a vacuum; rather, the available social forms and, of course, our interactions with others help shape it." While the verb re/membering suggests that the recapturing of 


\section{Ethnic Studies Review Volume 32.1}

indigenous identity is anchored to a memorial recollection of the past, it is also true that its etymology refers to the act of putting together the individual —and, by extension, the collective- body again in the present time. Far from advocating the idea of an authentic indigenous identity — which, for that matter, would be quite in tune with the act of stereotyping itself_- I propose resorting to the paradigm "individual (and collective being) rooted in place and place intertwined with time" in dynamic terms and look at it as a foundational principle for the construction, transformation and understanding of indigenous identity across history.

As I will discuss more in-depth in the next section, far from being an alienating act, digging into one's own personal story, that is to say "taking history so personal" is instrumental to the decolonization of the mind, an obliged passage for the successive (and successful) deconstruction of official historical narratives. In so using the word as a means to explore and to inquire into family and personal history, the writer detects the wounds left by centuries of genocide and Eurocentric "problematic acculturation." Nez-Perce Chicana/Tejana scholar and writer Inés Hernández-Ávila also suggests how integral the act of creativity is to the process of autonomy and therefore to the assertion of both individual and collective values, "Lo que está en juego es nada menos que la creación misma, porque la creatividad, el acto creativo, rechaza el control e insiste en la autonomía, tanto al nivel individual como al colectivo." In this context, the creative act constitutes a tool of discovery and recovery that, along with imagination, allows for the re-shaping of reality from the ontological and epistemological standpoint of the "oppressed." not only does such a process allow for a re-examination of traditional cultural values but it offers the space to fight back against past and ongoing politics of conquest and colonialism.

The re-telling of oral traditions is, therefore, the quintessential embodiment of a decolonizing act that integrates ritual, collective memory and present time in the restoration of holistic, cosmocentric ontologies; that is to say, the cosmos, and not the human being, lies at the center of existence. The reciprocal, dynamic relationship between community, tribe and nature becomes therefore essential 
to the nourishment of what we can call "chorographic ideologies;" these refer to the practice of specific languages, religions, territorial sovereignty and self-determination as inalienable ethnic rights.

Guillermo Delgado's illuminating insights into the notion of indigeneity sheds further light onto this, "indigeneity is a coming together, or re/membering of a native ethic, it articulates renewed senses of being in society and community, beyond anthropocentricity." As he goes on to explain, not only does such a view debunk the foundations of anthropocentrism, but it also offers precious contributions to an understanding of ethnicity in terms of cultural constructivism. The dynamic, multidimensional and "mobile" notion of indigeneity subscribes to the view of a topos that embraces the migratory experience as a transformative, regenerative process of individual and collective identity formation, which is at best expressed by the voices of uprooted indigenous groups (and living away from their ancestors' lands) now speaking from different places and historical moments.

Territoriality transcends the limits of geographical notions of space, and finds its most eloquent explanation in the metaphor of a $\mathrm{re} / \mathrm{membered}$ body, an "inhabited territoriality" where indigenous people re-discover and simultaneously experience their histories, heritages, and sense of belonging both at home and across borders. This "coming together" legitimizes the articulation of several, different stories as integral parts of a polyphonic universe whose vision is based, similarly to the natural world, on the cultural logic of (bio)diversity and multiplicity, "Diversity, on the other hand, as defined by Scott, "refers to the plurality of identities, and it is seen as a condition of human existence rather than as the effect of an enunciation of difference that constitutes hierarchies and asymmetries of power."

As I will further elucidate in the next section, any discussion of indigenous experience needs to acknowledge this sense of responsibility towards the land and its geocentric role; in quoting Lakota writer Cook-Lynn's notion of "language of place" as the one that literally and — I would add — symbolically embodies the space where culture is reproduced, Varese suggests that "a paradigmatic shift that accentuates topos rather than logos is needed to 


\section{Ethnic Studies Review Volume 32.1}

understand indigenous people." In this context, the revitalization of indigenous languages in literary and visual narratives has offered major contribution to the refashioning and dissemination of localized, historical narratives such as origin, migration stories, and legends.

\section{Choosing the right word: repositioning knowledge the self, and the community within the cosmos}

The details of my story are given here not as a point of interest in and of themselves but as a vehicle to deconstruct the images of Indians as victims in this war dance in the blood of colonization (Gloria Bird)

The works of indigenous writers in Mexico and the U.S., as well as of community videomakers, eloquently speak to the cultural producer's responsibility in the dissemination and reinforcement of the community's voice(s) and of what I would call a "cosmo-historical" identity. In the latter, I condense the idea according to which - as I explained earlier - indigenous identity cannot be understood out of indigenous paradigms of space, time, and community. In this sense, both written and visual narratives constitute the space where the author grounds her/his own epistemological message. Specifically, I argue that the narratives under examination account for enduring believes in ways of living, of expressing one's own individuality in society and sense of belonging to the community that are totally foreign to the effects of modern alienation and individualism. Although dominant societies have often portrayed indigenous cultures as static and conservative, these works show that resistance to assimilationist practices can translate into a dynamic negotiation, dialogue and mutual transformation between different traditions. Given the crucial role that oral tradition has been playing in the survival of Native American cultures, these new narratives shed light onto a multiplicity of longstanding, native imaginaries that constitute the soil of indigenous peoples' worldviews. Leslie Marmon Silko's "The Pueblo Migration Stories" illustrates this quite eloquently: here she elaborates on the openness of migration stories' structures 
and pinpoints the pivotal role that the community fulfills in their transmission. The end result being, as she goes on to explain, that the truth emerging from this cycle is a "communal" vis-à-vis an "absolute" one, "The ancient Pueblo people sought a communal truth, not an absolute truth. For them this truth lived somewhere within the web of differing versions, disputes over minor points, and outright contradictions tangling with old feuds and village rivalries."

In contrast to western dogmatism, the validation of several, loose versions of the same story emerges from an epistemological framework that finds its raison d'être in pluralistic and diversified views of existence that change over time and generations. The memory of Silko's community constitutes, therefore, a space of identification where Laguna pueblo people share the same roots and ancestry, but also where future generations can create new meanings and refashion the complexities and dynamism of tradition in their own terms, "Las culturas indígenas son (y eran) complejas, no monolíticas, sino llenas de contradicciones, ambuiguedades, conflictos, préstamos, innovaciones, (re)creaciones." The transformative process embedded in storytelling contributes also to the enhancement of collective consciousness whereby indigenous people simultaneously perceive themselves as subjects and objects of their own, original "stories." Although, from a theoretical standpoint, the subsequent processes of selection and editing (especially with regard to video production) can nonetheless make the replication of these narratives partial and reified, from a political perspective the articulation of the voice "from within" is crucial to break up the silence imposed by centuries of colonial and patriarchal oppression.

As I previously mentioned, not only do these works emerge and spread out in consonance with ongoing struggles for autonomy and self-determination, but they also express indigenous people's will to appropriate and transform western ways of producing knowledge. With regard to this, Nahuatl scholar Natalio Hernández remarks that in the cultural encounter between native and mainstream cultures, indigenous people strip themselves of the stereotypical labels of primitive, inarticulate, mythical and exotic perpetuated 
by colonial, evangelical and - I would add - twentieth-century indigenist discourse. Hence, in the works of Javier Castellanos and Victor de La Cruz, Natalio Hernández, Benjamin Gonzales Urbina, Gerardo Can Pat "podemos encontrar otra vision de lo indigena otra forma de interpretar lo cotidiano, lo circunstancial, lo sagrado y otros valores autóctonos."

Most importantly, such narratives conflate into a decolonized conceptualization of a "territorial identity" which subscribes to a critique of an ideology that considers the values underlying the moral foundation of indigenous peoples' cultures as backwards and antithetical to the dominant modern world order. Besides being informed by an "emic" native perspective, territorial identity departs also from postmodern theorizing.although paving the way to a radical critique of western scientific axioms, this has overlooked — if not failed to acknowledge — the values and ethics of indigenous cultures. Not only does the act of territorial re/ membering advocate specific histories and ways of producing and passing down knowledge, but it also reconnects the individual to him/herself and to the community by means of what Assiniboine/ Nakota scholar Kathryn Shanley calls a "thinking heart."

Hence, the territorial body-metaphor stands for an everlasting encounter between the human being and the place, a returning home that, in so transcending most recent theorizing on the individualized body, aims at restoring the "members" of the community to their original birthplace. In this context, the use of indigenous languages in the works of Mexican writers and videomakers undoubtedly contributes to the preservation of traditional stories, myths, and local ethnic values and, most importantly, it allows to regain control over a wide, diversified range of both natural and cultural resources, and a relationship with the world whereby the human being finally re-knows the "sacred forces of nature." In the video "Searching for Well-being" (directed by Guillermo Monteforte and María Santiago Ruíz) Eucario Angeles explains in Zapotec how the homonymous organization was started with the precise goal to rediscover and restore traditional ways of living "las señales, los cuentos, las formas de antes: el conocimiento de como vivir.... aunque los padres no fueron a la escuela...las costumbres de 
antes... [para] revivirlas y usarlas."

More specific in theme, the video El arbol del jabón revolves around Zapotec people's resistance to an economic system that exploits and eventually destroys the natural environment. Here, a group of women from one of the rural communities in the municipality of San Pedro Quiatoni decide to do away with the laundry detergents advertised by the media, and to learn the techniques for the homemade production of soap. The idea of resorting to a plant that grows in the area as well as the conscious and ecological use of it brings us back to the deeply engrained notion of reciprocity between nature and human labor. The elders' knowledge - that, in this case, is epitomized by la abuela Rosaand oral tradition are pivotal in the perpetuation of a lifestyle that is constantly jeopardized by the logics of consumerism and of market economies. By the same token, the dialogues in Zapotec reinstate the women's sense of belonging to a community that, however constantly exposed to the national language (Spanish) - this being successfully conveyed by the commercial appearing on Dona Juana's TV set at the beginning of the story - still identifies itself with the language of the ancestors and of the place.

Interestingly, the "critique" of market economy portended in these narratives provides also the ground for engaging discussions on the social values of indigenous communities: as I previously mentioned with regard to Silko's essay, community elders and ancestors are the "teachers" and depositaries of the knowledge of place and nature. showing the centrality of the elders' in the oral transmission, from time immemorial, of agricultural techniques, weather forecasting, economic and trade systems, both of these videos critically respond to the mainstream "consecration" of the youth as the only actor in the economic and cultural progress of society. In a similar fashion, in her short story "Lo que contaron nuestros abuelos y tatarabuelos," Tojolabal writer María Rosaria Jimenez looks at the elders as central figures in the preservation of the community's "collective memory." Although I am aware of the scholarly debate around the term, in this specific context I refer to collective memory as a self-representational practice that the community carries out by means of the oral tradition and therefore 


\section{Ethnic Studies Review Volume 32.1}

in contrast with the historiographic process that - whether it is performed by the indigenous or non-indigenous intellectualis ultimately individualist. Conversely, this way of constructing history "orally" lacks in the critical and analytical approach that characterizes the historiographic method, but it nonetheless gives both the writer and the community the simultaneous roles of "authors," "readers" and "listeners." Thus, in so representing themselves through the story or the myth, they articulate their own agency in the weaving and in the perpetuation of the community's history. Most importantly, the story being told is never the same one within the same group and is therefore subject to the contingency of specific historical moments, social dynamics, and power relations.

Esto contaban nuestros abuelos y tatarabuelos sobre el Ixk'inib', cerro que acompaña al pueblo tojolabal Lomantam del municipio de las Margaritas [. . .] Ese cerro poseía un tesoro del que unicamente podían disfrutar gentes dotadas de sabiduría y encantamiento. Ese cerro es el Ixk'inib' de Lomantam. Ahí los abuelos escogidos disfrutaban de ese misterio del interior. Otros hombres lo intentaron, penetraron y nunca encontraron nada. Pero ellos decían que todo lo conseguían en un pintoresco y exuberante lugar, incomparable. [. . .] El cerro de ahí está haciendo compañía al pueblo tojolabal de Lomantam y conservando en su interior el recuerdo de nuestros abuelos.

These passages undeniably illuminate the enduring, magic relationship between the territory, its creatures and the word; here creativity fulfills the role of both originator and truth seeker, and reinscribes both the self and the community within their own, cosmological time and place. As Silko would say, "Whatever the event or the subject, the ancient people perceived the world and themselves within that world as part of an ancient, continuous story composed of innumerable bundles of other stories [ . . .] Pueblo oral tradition necessarily embraced all levels of human experience."

Similarly, in the introduction to the volume Speaking for 
the Generations, Simon Ortiz accounts for the "mythic source" of his people's existence and goes on to elucidate how native contemporary writing pays homage to traditional ways of living and to an endless cycle of cultural renovation,

Acoma Pueblo people believe they came into existence as a human culture and community at Shipapu, which they know as a sacred mythic place of origin [. . .] This belief is expressed time and time again in traditional song, ritual, prayer, and story, and in contemporary writing. Verbalizing, articulating, and practicing in social and religious activities today is simply carrying on a traditional way of life.

Quite significantly, this passage raises the concept of autonomy as an individual act -namely the author's freedom and will to articulate his and his people's belief system - and as a collective one - i.e. the community's right to exert it as a day-to-day practice and in relation to other external collectivities such as the nation itself. However, it is also important to note that Ortiz's timeless notion (in the indigenous sense of the word) of a resiliently alive "sacred mythic place of origin", invites us to relocate our sociopolitical definition of autonomy within a more philosophical —if not religious - terrain. "Territorial autonomy" is, in this sense, autonomy, sovereignty of time, embedded in a cosmological history that knows no boundaries between the tangible and the intangible world,

En forma humana deambulan

En la soledad de la noche.

Jinetes de caballos dorados

Que roban espiritus ingenuos.

Guardianes de la tierra

Que recolectan tributes.

Ojos de la luna que vigilan la noche.

Reflejos de estrellas

Que iluminan el cielo.

Native American visual production in the United States also puts forward themes that revolve around the survival of indigenous 


\section{Ethnic Studies Review Volume 32.1}

identities, cultural and religious values in today's society. The documentary In the Light of Reverence (2001), co-produced by Christopher McLeod and Lumbee Malinda Maynor offers a compelling analysis of the ways in which Indian Country has been responding to the governmental policies that jeopardize religious practices, territorial and cultural sovereignties. Even though the narrative specifically focuses on three tribal experiences (the Lakota and Devil's Tower, the Hopi and the Colorado Plateau, and the Wintu and Mt. Shasta), it nonetheless opens up a discussion on how the American Indian Religious Freedom Act (AIRFA) first signed in 1978 is still mostly overlooked and violated by the U.S. government.

The narrative portends two "antithetical" perceptions of the land as a sacred site and as a commodity through the voices of spiritual leaders, elders, indigenous and non-indigenous scholars, lawyers, park officers, local people, and entrepreneurs. Doing so, it invites the viewer to reflect upon the challenges that different cultural and religious systems inevitably bring about. To what extent are these reconcilable? And if so, how? Rather than trying to give a specific answer to the complexities of such an issue, the video aims at arising knowledge and educate the U.S. public on indigenous communities' sacred places.

For the indigenous groups presented, the right to practice religious ceremonies is embedded in the respect and preservation of the landmarks that carry symbolic meanings about the genesis, history, and spiritual existence of their peoples. For example, in the section on the Colorado Plateau, one of the Hopi spiritual leaders brings to the viewer's attention the role that petroglyphs have in the preservation of local history. As we previously discussed, the land is traditionally the carrier of indigenous peoples' sense of time and existence in their place of origin. The loss of such a cultural and existential patrimony to the advantage of large-scale infrastructural projects is thus detrimental to the perpetuation of tribal knowledge and conceptualizations of history that, in this case, are undoubtedly "geophysical" in nature. In a similar way, the (voice over) narrator's recounting of creation stories and myths of origin at the beginning of each section emphasizes the foundational role of the oral tradition 
in the explanation of the world outside western paradigms. The stories presented throughout the documentary propose, over and over again, cosmovisions and narrative structures centering on the interdependence between the supernatural, animal, vegetable, geological and human worlds alike. Altering such a balance has thus damaging consequences not only on the physical existence of the earth, but also on the spiritual and intellectual formulation and survival of local knowledge.

While documentary making is widely used as a tool that helps foster first person testimonial narratives, fiction allows indigenous and mixed-blood filmmakers to question mainstream representational paradigms even more directly and effectively. In most cases, Hollywood cinematic production and popular culture have contributed to reify Native American peoples and represent them either as "Wild West" savages, sports mascots, touristy attractions, or commercial icons. Although this topic would make for another entire essay, it is worthwhile pointing out that feature films by Spokane/Coeur D'Alene writer Sherman Alexie (The Business of Fancy Dancing, 2002) and Cheyenne/Arapaho director and producer Chris Eyre (Smoke Signals, 1998 and Skins, 2002) constitute strong critiques of mainstream representations of indigenous identities. In particular, they bring to our attention the transformative power of "independent" cinematic narratives by First Nation directors/screen-players within the arena of popular media culture. Endowed with cunning touches of irony and sarcasm, Alexie and Eyre's works sharply address the complexities of contemporary indigenous and mixed-blood identities both inside and outside the reservation "boundaries."

Unlike the documentaries previously discussed, the stories presented in these movies primarily revolve around the personal experiences of some young men and women who come to terms with the challenges and plights of living across "different worlds." In Smoke Signals, Victor, a Cour d'Alene Reservation Indian sets off on a journey to recover the body of the dead father, Arnold -an abusive, alcoholic man - only to come to a deeper understanding of his own, indigenous identity and of the reasons behind Arnold's alcoholism. Although, at first glance, the movie seems to do 


\section{Ethnic Studies Review Volume 32.1}

nothing but perpetuate the stereotype of dysfunctional Native American reservation life, indeed its ultimate goal is to show that racism, marginalization, and poverty are colonial legacies that still affect the lives of indigenous people and especially of younger generations. But characters like Victor demonstrate that, in order to heal, it is imperative to go through a process of self-analysis that will allow the individual to develop a more constructive attitude towards the plight of his immediate family and of the reservation.

A critical look at these recent productions along with those by many more U.S. indigenous film and videomakers such as Navajo Sydney Freeland, Shonie de la Rosa, Rachael J. Nez, Bennie Klain, etc. disproves the generalized idea according to which all indigenous people have by now given in to the forces of assimilation. In the same way as the proliferation of community video-documentary projects in Mexico - and, for that matter, throughout the Americas - testifies to the proactive stance of younger generations in their people's struggles for self-determination, the increasing numbers of fictional narratives at indigenous Film Festivals, international conferences, forums and TV channels in the U.S. speak to indigenous peoples' ongoing questioning and will to bring onto the table discussions about their own sense of ethnic belonging to (or alienation from) both their communities of origin and mainstream society.

\section{Conclusion}

The purpose of this essay has been to discuss the importance of a hemispheric approach to the study of indigenous people, to look at the intersections of indigenous identity and territoriality, and to understand creativity in relation to processes of autonomy and decolonization. The centrality of the landbase in the narratives here presented is illustrative of a sense of being in and knowing the world that, despite centuries of foreign domination and exploitation, continues to inform the lives of indigenous peoples throughout the Americas today. Most importantly, from a theoretical standpoint, these texts bring forth the centrality of human faculties such as creativity, imagination and memory in the shaping of representational narratives that critically respond to centuries of stereotyping and misrepresentation. In order to better understand 
this, it is necessary to contextualize issues of cultural production and survival within a framework that while valuing the contribution of each single community and tribal history emphasizes the collective work of indigenous people in the international arena.

While I was writing a first draft of this essay, the state of Oaxaca was hosting the VIII Festival Internacional de Cine $y$ Video de los Pueblos Indígenas, "Raíz de la imagen:" the event had the goal not only to foster the production and dissemination of community video projects, but also to reinforce networking between indigenous audiences and videomakers from Latin America. Even if, as videomaker Guillermo Monteforte once stated in a conversation with me, there is still a lot of work to do in this direction - given the political and social reality that the communities have to struggle with on a daily basis, the impact of video production is still marginal and temporary - events like this and resilience on the part of community activists give hope and optimism for the future of indigenous video making.

By the same token, writing in indigenous languages (as in the case of Mexican writers) or appropriating English (as in the case of U.S. Native American writers) helps re/member and carry on ways of signifying the world that call for a reformulation of identity, creativity, territoriality and community cohesion primarily based on an indigenous framework. If on the one hand, literature in indigenous languages (vis-à-vis Spanish) inevitably addresses specific and limited audiences, on the other it plays a primary role in the development and dissemination of bilingual education programs in Mexico. These, besides fostering diversity, constitute an integral part of a decolonizing agenda that promote the legitimization of indigenous languages in the processes of nation building not only at home, but also within the context of transnational, diasporic experiences.

\section{Notes}

* This article has gone through several revisions, and has benefited from the insightful comments of Stefano Varese, Guillermo Delgado and Sergio de la Mora along the way. I am also grateful for the precious suggestions of the anonymous reviewers for the Ethnic Studies Review

i The past thirty years have witnessed an unparalleled development of 


\section{Ethnic Studies Review Volume 32.1}

ethnopolitical movements; hence, I look at these literary and visual projects as some of the most illustrative contemporary examples of resistance through selfrepresentation. Although, for the purpose of this essay, I have limited my time frame to the last twenty years of production, we need to remember that a long legacy of "anti-colonial" texts produced by indigenous people has been in place since the beginning of Colonialism . Hence, the importance of looking at these narratives as part of a long-term process of cultural resilience.

ii See Inés Hernandez-Ávila, “¿Qué está en juego? Las comunidades indígenas México/Estados Unidos," in Renacerá la palabra. Identidades y diálogo intercultural, ed. José Manuel Valenzuela Arce (México, D.F.: El Colegio de la Frontera Norte, 2003), 155-172.

iii Angela Cavender Wilson, "Reclaiming our Humanity. Decolonization and the Recovery of Indigenous Knowledge," in Indigenizing the Academy. Transforming Scholarship and Empowering Communities, eds. Devon Abbot Mihesuha and Angela Cavender Wilson (Lincoln and London: University of Nebraska Press, 2004), 69-88. In her work, Dakota historian Angela Cavender Wilson addresses the issue as to how history has been written by non-indigenous scholars and argues for a decolonizing methodology that gives centrality to oral tradition and that voices the point of view of tribal members. "Reclamation of indigenous knowledge is more than resistance to colonial domination, it is also a signifier of cultural revitalization and mounting Native nationalism".

iv The first term refers to indigenous people in Mexico and the second one to the U.S., i.e. to the nation to nation relationship between tribes and the U.S. government, as the history of treaties illustrates.

v As I imply throughout my essay, this type of research moves in the direction of decolonizing scholarship: its main purpose is to start precisely from the demands of the communities under examination as a gateway to the understanding and reformulation of indigenous experiences in indigenous terms and therefore to the legitimization of "non-academic" knowledge. I subscribe, therefore, to the gramscian notion of "organic intellectual" who commits to the community he/ she is working with, as well as believe in the political and social role that the researcher plays in bridging the gap between the academia and the outside world.

vi "Interview with Tomás Ybarra-Frausto: The Chicano Movement in a Multicultural/Multinational Society," in On edge: the crisis of contemporary Latin American culture, eds. George Yúdice, Jean Franco and Juan Flores (Minneapolis: University of Minnesota Press, 1992), 214.

vii Stefano Varese, "The Territorial Roots of Latin American Indigenous Peoples' Movement for Sovereignty," in The Future of Indigenous Peoples. Strategies for Survival and Development. eds. Duane Champagne and Ismael Abu-Saad (Los Angeles: UCLA American Indian Studies Center, 2003), 48-65. 
viii Franke Wilmer, The Indigenous Voice in World Politics (London: Sage Publications, 1993), 7.

ix Octavio Paz, "México y Estados Unidos. Posiciones y Contraposiciones. Pobreza y Civilización" (1978) in his El Laberinto de la Soledad (Madrid: Ediciones Cátedra, 1998), 451.

$\mathrm{x}$ In this context, I use the term "genocide" as Native American Studies scholars in the U.S. have appropriated it in order to explain the deliberate act of extermination carried out against the indigenous peoples of the Americas. Nevertheless, I am aware that, historically, colonization has followed different paths in the several regions of the two hemispheres: accordingly, indigenous peoples' existence has been affected in various ways and degrees (physically, culturally, emotionally, etc.). Hence, in some cases it would be more appropriate to use the term "ethnocide", namely the intentional eradication of a culture and ways of life in order to subjugate its people.

xi Shelton Davis, "Globalization and Traditional Cultures" Northeast Indian Quarterly (Spring 1991): 42.

xii Carlos Montemayor and Donald Frischmann, eds. Words of the True Peoples. Palabras de los Seres Verdaderos (Austin: University of Texas Press, 2004).

xiii VI Festival Americano de Cine y Video de los Pueblos Indígenas, Guatemala 1999.

xiv Terence Turner, "Defiant Images: The Kayapo Appropriation of Video" Anthropology Today 8 (1992): 10.

xv Jamie Brown and Tara Tidwell Cullen, "Indigenous People at the World Summit on the Information Society" Cultural Survival 29 (Spring 2005): 13.

xvi Wilmer, The Indigenous Voice in World Politics, 55.

xvii Stefano Varese, “Una dialéctica negada. Notas sobre la multietnicidad mexicana" in En torno a la cultura nacional (1980): 148

xviii It is important to note, however, that this essay was first published in 1976 and, ever since, the author has been redefining his position in relation to this issue by adopting a hemispheric approach to the understanding of indigeneity.

xix See Linda Tuhiwai Smith, Decolonizing Methodologies (New York: Zed Books Ltd., 2001). Although mostly focusing on Maori research and methodology, Tuhiwai Smith's work offers great contribution to the re-thinking and re-formulation of indigenous knowledge within the academia. In the chapter "Twenty-five Indigenous Projects" she clarifies how struggles for selfdetermination, healing, reclaiming, cultural survival, etc. have been taken up 


\section{Ethnic Studies Review Volume 32.1}

both by indigenous researchers and community activists. Their work has thus been articulated into a series of research projects that constitute, in their turn, an overarching research agenda.

In this essay, I am also formulating an operational use of the concept of culture within a dialectical perspective: specifically, I refer to culture as a system of values, social practices, symbolic and spiritual meanings that are constantly shifting and re-adapted to new historical and social contexts.

xxi Obviously, here I mean land in its broader meaning (nature, environment, home, etc...). For further reference, see Stefano Varese and Michael Grofe, “Notas Sobre la Territorialidad, Sacralidad y Economia Politica: Tercera Mesa Redonda de Monte Alban" UC Davis: Indigenous Research Center of the Americas, Department of NAS, no. 4 (2002), HYPERLINK "http://repositories. cdlib.org/irca/territoriality/4/" http://repositories.cdlib.org/irca/territoriality/4/

xxii Sandy Marie Anglás Grande, "American Indian Geographies of Identity and Power: At the Crossroads of Indígena and Mestizaje" Harvard Educational Review 70 (Winter 2000): 482.

xxiii Kwame Anthony Appiah, Daedalus, "The politics of identity" Daedalus (Fall 2006): 18.

Such a perspective also invites us to reiterate the symbolic function of territory and time in the articulation of ethnic identity, "En el territorio étnico el tiempo y el espacio se conjugan, ya que allí ha transcurrido la experiencia vital que da sustento a la memoria histórica de la sociedad. [. . .] De todas maneras la tierra sigue proporcionando un sustento possible a la identidad, incluso entre los grupos migrantes cuyas tierras ancestrales se transforman en referentes mitificados." Miguel Alberto Bartolomé, Gente de Costumbre y Gente de Razón. Las identidades étnicas en México (México D.F.: Siglo Veintiuno Editores, 1997), 87-89.

xxiv See Guillermo Delgado, note xxvi.

xxv Hernández-Avila, “Tejana Intonations/Nez Perce Heartbeat: Notes on Identity and Culture" a/b: Auto/Biography Studies 7, no. 2 (Fall 1992): 292-306. Native American writers such as Gloria Bird (Spokane), and Inés HernándezAvila often address issues of "decolonization of the mind" and the rewriting of official history in response to centuries of assimilation policies carried out by the U.S. and Mexican governments. Along with land expropriation, forced acculturation, and Christianization were aimed at the psychological, spiritual and emotional colonization of native peoples. Therefore, I claim that the works by contemporary indigenous and mixed blood cultural producers analyzed in this essay and elsewhere in my research emerge from processes of self (and collective) discovery and inquiry that by acknowledging the disruptive effects of colonization also envision the possibility of the recovery and revalidation of indigenous ways of being in the world. 


\section{Fachin-Inside the Image and the Word}

xxxvi Hernandez-Ávila, “QQué está en juego? Las comunidades indígenas México/Estados Unidos", 170.

xxvii See Guillermo Delgado, "Imagin/ing Border Indigeneity: Two Notes on Decolonization and Sp(I)ace," Unpublished manuscript, 2005. I seize the opportunity to thank Guillermo Delgado to let me quote material from this essay.

xxviii Ibid.

xxix For further clarifications see Carlos Alberto Torres, "Education in Latin America and the Caribbean: A Theoretical Discussion of Citizenship, Democracy, and Multiculturalism," in The Future of Indigenous Peoples. Strategies for Survival and Development, 75-103. "People identify themselves in certain ways in order to protect their bodies, their labor, their communities, their way of life; in order to be associated with people who ascribe values to them; and for purposes of recognition, to be acknowledged, to feel as if one actually belongs to a group, a clan, a tribe, a community. So that anytime we talk about the identity of a particular group over time and space, we have to be very specific about what the credible options are for them at any given moment" (Cornel West 1996: 57 in Torres, 88).

xxx Torres, "Education in Latin America and the Caribbean: A Theoretical Discussion of Citizenship, Democracy, and Multiculturalism," 88.

xxxi Varese, "The Territorial Roots of Latin American Indigenous Peoples' Movement for Sovereignty," 51.

xxxii L.M. Silko, "Writing a "Witness,"'" in Speaking for the Generations. Native Writers on Writing, ed. Simon Ortiz (Tucson: University of Minnesota Press, 1998), 10.

xxxiii Hernandez-Ávila, “¿Qué está en juego? Las comunidades indígenas México/Estados Unidos," 171

xxxiv Juan Gregorio Regino, "Escritores en lenguas indígenas," in Situación actual y perspectivas de la literatura en lenguas indígenas, ed. Carlos Montemayor (San Angel D.F.: Consejo Nacional Para la Cultura y las Artes, 1993), 133-134.

xxxv Wilmer, The Indigenous Voice in World Politics.

xxxvi Kathryn Shanley, "The Thinking Heart: American Indian Discourse and the Politics of Recognition," in Race, Ethnicity, and Nationality in the United States: Toward the Twenty-First Century, ed. Paul Wong (Boulder: Westview Press, 1999), 256-276.

xxxvii As Delgado infers in his manuscript "Imagin/ing Border Indigeneity: Two Notes on Decolonization and $\mathrm{Sp}(\mathrm{I})$ ace," with regard to Raul Prada Alcoreza's 


\section{Ethnic Studies Review Volume 32.1}

work on territoriality,

"Obviously Prada Alcoreza is establishing a clear intertextual dialogue with an ethnography that paid too much attention to the human body-metaphor in the thought of Quechua Ayllu Kaata members (in the Bolivian Andes) inhabitants that have always considered their territory parts of the human body and its functions, the body metaphor of land and water kinetics. (Bastien 1978)."

xxxviii Gabriela Coronado Suzan, "La literatura indígena: una mirada desde fuera," in Situación actual y perspectivas de la literatura en lenguas indígenas, 55-74.

xxxix One of the founders of the local organization Buscando Bienestar (Municipality of San Pedro Quiatoni, Oaxaca).

xl Santiago Ruíz María and Martinez Reyes Eugenia, dir. Buscando Bienestar. Grupo Solidario Quiatoni, 1997.

xli That is to say, the transcriber of the community's oral repertoire.

xlii María Rosaria Jiménez, "Lo que contaron nuestros abuelos y tatarabuelos," in Words of the True Peoples. Palabras de los Seres Verdaderos, 152.

xliii L.M. Silko, "Writing as "Witness,"” 8-9.

xliv Simon Ortiz, "Wah Nuhtyuh-yuu Dyu Neetah Tyahstih (Now It Is My Turn to Stand)," in Speaking for the Generations. Native Writers on Writing, xiv.

xlv Juan Gregorio Régino, "Los guardianes de la tierra," in Los Escritores Indígenas Actuales I, ed. Carlos Montemayor (San Angel D.F.: Consejo Nacional Para la Cultura y las Artes, 1992), 73.

xlvi Similarly to The Business of Fancy Dancing, the screenplay for this movie was also written by Sherman Alexie. 